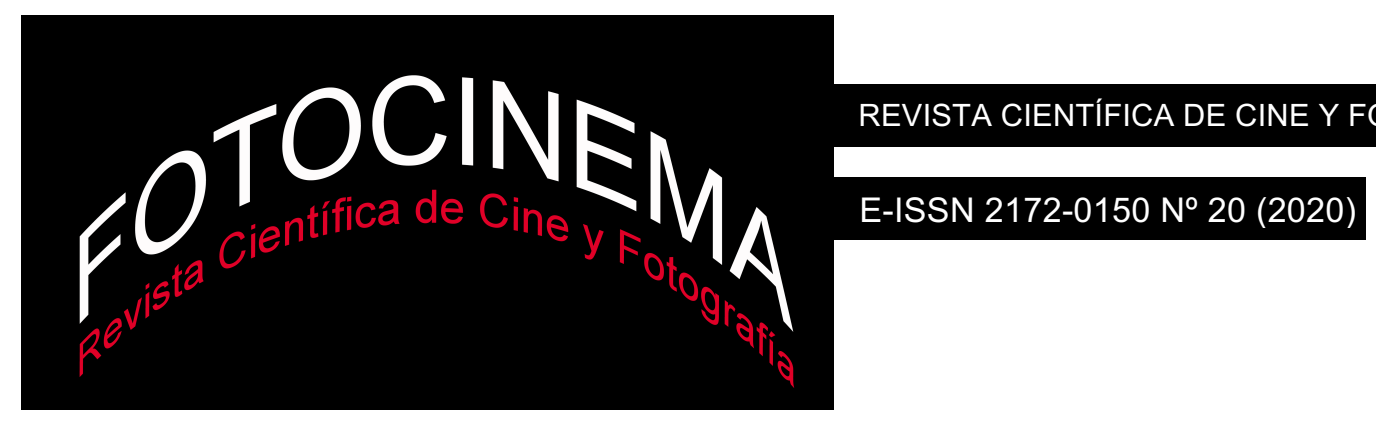

\title{
Aporias e apostas do representável: vazios e vestígios da memória em Os dias com ele (Maria Clara Escobar, 2013) ${ }^{1}$
}

\author{
Aporías y apuestas de lo representable: vacíos y vestigios de la \\ memoria en Los días con él (Maria Clara Escobar, 2013)
}

\section{Aporias and stakes of representable: voids and traces of memory in The days with him Maria Clara Escobar, 2013)}

\author{
Fernando Seliprandy \\ Universidade Federal do Paraná (UFPR), Brasil \\ seliprandy@hotmail.com
}

\section{Resumo}

O irrepresentável é uma matriz teórica recorrente nas análises do documentário subjetivo contemporâneo. Oriunda dos estudos do Holocausto, esta abordagem contém o trauma pessoal e histórico em seu núcleo, fundamentando várias considerações sobre o cinema documental realizado por descendentes de militantes vítimas das ditaduras do Cone Sul. O objetivo aqui é promover uma discussão acerca do representável a partir da análise de Os dias com ele (Maria Clara Escobar, 2013), documentário no qual a filha enfrenta as resistências do pai em relatar as torturas sofridas durante a ditadura brasileira (1964-1985). Os impasses da memória se manifestam com força nesse filme, em diálogos tensos e enquadramentos de um vazio eloquente. Contudo, junto com o reconhecimento das aporias da representação, é possível fazer outras apostas interpretativas. Se os vazios são plenos de significados, os vestígios do passado inscritos nas imagens também merecem atenção. A hipótese é que, no lugar do foco exclusivo nas aporias do irrepresentável, uma interpretação historiográfica dessa obra deve levar em conta, dialeticamente, os vazios e os vestígios da memória. Reivindica-se, assim, uma visada referencial que é não só epistemologicamente possível, mas politicamente urgente face à ofensiva negacionista que ganha cada vez mais espaço no Brasil pós2018.

\begin{abstract}
The unrepresentable is a frequent theoretical perspective in the analysis of contemporary subjective documentary. Coming from the Holocaust Studies, this approach brings the personal and historical trauma at its core, guiding several interpretations about documentaries directed by descendants of militants who were victims of the Southern Cone dictatorships. The aim here is to promote a debate on the representable with an analysis of The days with him (Maria Clara Escobar, 2013), a documentary in which the daughter faces her father's resistance to narrate the torture suffered during the Brazilian dictatorship (1964-1985). The uneasiness of memory is strongly manifested in this film, in tense dialogues and shots of eloquent emptiness. However, along with recognizing the aporias of representation, it is possible to take chances in other interpretative direction. If there are plenty of meanings in the voids, the traces of the past also deserve attention. The hypothesis is that, instead of focusing
\end{abstract}

\footnotetext{
${ }^{1}$ Este artigo é uma versão sintetizada e atualizada do Capítulo IV de minha tese de doutorado, intitulada Documentário e memória intergeracional das ditaduras do Cone Sul (Seliprandy, 2018, pp. 269-320).
} 


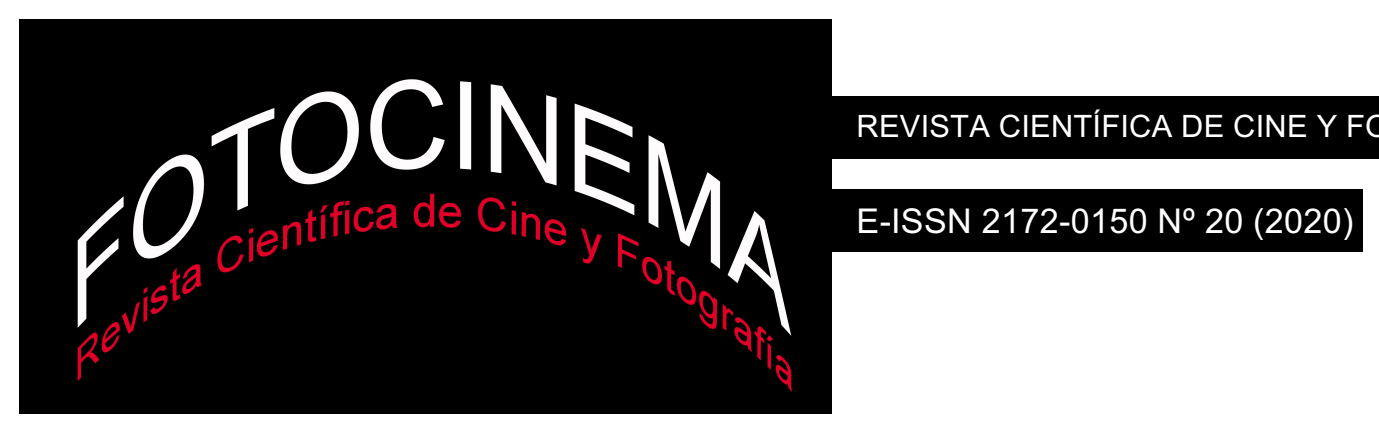

exclusively on the aporias of unrepresentable, a historiographical interpretation of this film should dialectically include the voids and traces of memory. It's claimed thus a referential gaze that is not only epistemologically possible, but politically urgent to face the negationist assault that is increasingly gaining ground in post-2018 Brazil.

\section{Resumen}

Lo irrepresentable es una matriz teórica recurrente en los análisis del documental subjetivo contemporáneo. Oriundo de los estudios del Holocausto, este acercamiento contiene el trauma personal e histórico en su núcleo, siendo la base de diversas proposiciones sobre el cine documental realizado por descendientes de militantes víctimas de las dictaduras del Cono Sur. El objetivo aquí es promover una discusión acerca de lo representable a partir del análisis de Los días con él (Maria Clara Escobar, 2013), documental en que la hija se enfrenta a las resistencias del padre a relatar las torturas sufridas durante la dictadura brasileña (1964-1985). Las entrevistas que la hija-directora intenta hacer con el padre, el filósofo, dramaturgo y ex militante Carlos Henrique Escobar, se transforman en una "pulseada" por el control del retrato biográfico a ser construido. La directora, habiendo armado el escenario en donde Carlos Henrique debería leer la orden de arresto expedida por los militares en su contra en 1973, recibe como respuesta una contundente negativa de su "personaje". La silla queda vacía. Este momento específico de Los días con él parece concentrar las premisas centrales de la idea de lo irrepresentable. Este plano sería una manifestación casi emblemática de dicha matriz teórica en el cine documental de los hijos de víctimas de las dictaduras de Brasil y del Cono Sur. Habiendo recibido tanta atención en los textos analíticos dedicados a Los días con él, es como si esta silla vacía fuera el signo de algo mucho más grande: las trágicas ausencias que impulsan las elaboraciones de las nuevas generaciones. Aquella silla en particular termina elevada a símbolo de una laguna constitutiva, de un abismo insuperable entre memoria y pasado, entre lenguaje y realidad. Es verdad que los obstáculos de la memoria se manifiestan con fuerza en esta película, en diálogos tensos y encuadres de un vacío elocuente. Pero, junto con el reconocimiento de las aporías de la representación, es posible hacer otras apuestas interpretativas. Si los vacíos son plenos de significados, los vestigios del pasado inscriptos en las imágenes también merecen atención. Cuando miramos el largo plano de la silla vacía de Los días con él hasta su final, el vacío de la representación y el documento histórico se chocan de forma potente. O más bien, la hija invade el plano, llena el vacío de la silla con su cuerpo, imponiéndose en la imagen, desobedeciendo la interdicción del padre al leer su orden de arresto. Vale la pena seguir a la hija en su desobediencia como parte de un ejercicio que acerque la película a los archivos de la dictadura, a los registros que son pruebas de las atrocidades perpetradas por el Estado terrorista en aquellos años. La hipótesis es que, en lugar de centrarse exclusivamente en las aporías de lo irrepresentable, una interpretación historiográfica de Los días con él debe tener en cuenta, dialécticamente, los vacíos y los vestigios de la memoria. Se reivindica así una mirada referencial que no solo es epistemológicamente posible, sino políticamente urgente frente a la ofensiva negacionista que cada vez gana más terreno en el Brasil pos-2018.

Palavras-chave: documentário; memória; filhos; ditadura; Brasil; negacionismo.

Keywords: Documentary; Memory; Children; Dictatorship; Brazil; Negationism.

Palabras clave: documental; memoria; hijos; dictadura; Brasil; negacionismo. 
De onde vem esse espaço que tem sido ocupado pelo negacionismo na arena da memória sobre a ditadura brasileira (1964-1985)? É à luz dessa inquietação, ancorada na conjuntura política do Brasil pós-2018, que este artigo revê criticamente a matriz teórica do irrepresentável, comumente empregada na análise do documentarismo subjetivo contemporâneo às voltas com experiências traumáticas. O objeto específico aqui é o documentário $O s$ dias com ele (Maria Clara Escobar, 2013), obra a partir da qual se desenvolverá um debate epistemológico sobre o representável que é, ao mesmo tempo, a reivindicação de um imperativo referencial.

A matriz do irrepresentável insiste nas aporias, nas impossibilidades, no caráter indizível e inimaginável do trauma pessoal e histórico. Nessa perspectiva, o real está sempre entre aspas, o vazio se impõe sobre a referencialidade. É claro que esse prisma tem sua pertinência. Afinal, após a "perda da inocência” epistemológica (Didi-Huberman, 2012, p. 132) que marcou as ciências humanas sobretudo na segunda metade do século XX, os impasses da representação são o ponto de partida de qualquer análise. Mas não necessariamente precisam ser o ponto de chegada.

Pois há um problema epistêmico e, pior ainda, um risco ético quando, na abordagem de um passado de violações de direitos humanos, a retórica do vazio domina a discussão sobre a memória; quando, enfim, as provas das atrocidades acabam soterradas pela ênfase teórica nas aporias da representação. Na conjuntura em que as vozes negacionistas se levantam com tamanha estridência no Brasil, a retórica do vazio termina sendo uma ameaça à memória, a despeito de suas boas e legítimas intenções.

A problematização do irrepresentável faz aqui dois movimentos: por um lado, trata-se, certamente, de levar em conta as lacunas e fissuras da memória visíveis em Os dias com ele; por outro, há um esforço de retirar a interpretação da zona abissal do irrepresentável, incluindo a prova documental na dialética entre vazio e vestígio. A hipótese é que esta aposta referencial (Ginzburg, 2011a, p. 276) talvez sirva de antídoto contra o negacionismo; que é urgente ocupar, com a afirmação da concretude das 
atrocidades, um espaço que acabou sendo deixado vazio entre as aspas por tanto tempo impostas ao real.

\section{O abismo do irrepresentável: variações em torno de uma cadeira vazia}

Em Os dias com ele, as entrevistas da filha-diretora com o pai, o filósofo, dramaturgo e ex-militante Carlos Henrique Escobar, transformam-se em uma queda de braço pelo controle do filme, uma acirrada disputa pelo retrato a ser construído, reverberando um passado e um presente de desencontros políticos e familiares. Em termos formais, esta obra em particular é extremamente simples: a filha com sua câmera filma o pai dentro de casa, com golpes de zoom abruptos, enquadramentos desajeitados, seguindo uma fatura fílmica muito próxima do cinema doméstico (Álvarez, 2010; Odin, 2010); os momentos supostamente anteriores e posteriores às entrevistas propriamente ditas são mantidos na edição final; a voz over da diretora só se manifesta esporadicamente, acompanhando algumas das inserções de filmagens em super-8 de famílias alheias, sem que aquela voz carregue a narrativa, sem que estes arquivos sobrecarreguem a tela; não há trilha sonora incidental extradiegética; nada de travellings itinerantes, tampouco legendas ou intertítulos. No limiar da precariedade estilística, despojado dos bemacabados códigos cinematográficos do documentário subjetivo contemporâneo, Os dias com ele teria tudo para ser mais "um filme que você liga a câmera e coloca um entrevistado na frente” (Bernardet, 2003, p. 286).

Mas não é esse o caso. Pois é justamente o flerte com o precário que faz com que a entrevista nunca seja asséptica nesse documentário. Ela traz consigo todos os ruídos do processo de filmagem, junto com as tensões entre campo e "antecampo" (Brasil, 2013). O espectador tem diante de si as disputas escancaradas entre a cineasta (a filha que pena para dirigir seu filme) e o entrevistado (que jamais renuncia à autoridade patriarcal e intelectual). É dessa fricção que surge o interesse de Os dias com ele. A persona fílmica de Carlos Henrique Escobar insiste em se impor com sua arguta inteligência, ao mesmo tempo ranzinza e espirituosa. Maria Clara Escobar vai revelando aos 
poucos os sutis poderes de uma ingenuidade astuta. A montagem de Júlia Murat e Juliana Rojas, outro ponto forte do filme, organiza esse cabo de guerra de modo a que os vaivéns das rusgas nunca soem maçantes.

Tudo isso fez com que Os dias com ele fosse calorosamente acolhido nos círculos especializados, desde que despontou no panorama cinematográfico brasileiro. Logo de entrada, em janeiro de 2013, ele foi premiado na Mostra de Cinema de Tiradentes como melhor filme da seção Aurora, tanto pelo júri da crítica quanto pelo júri jovem. Depois vieram as análises em congressos e artigos acadêmicos, em abordagens monográficas ou comparativas. Não por acaso, é de uma de suas falas que derivou o título da mostra "Silêncios históricos e pessoais”, ocorrida na capital paulista entre março e abril de 2014, a qual teve um importante papel na divulgação de documentários latino-americanos dessa vertente (Barrenha \& Piedras, 2014).

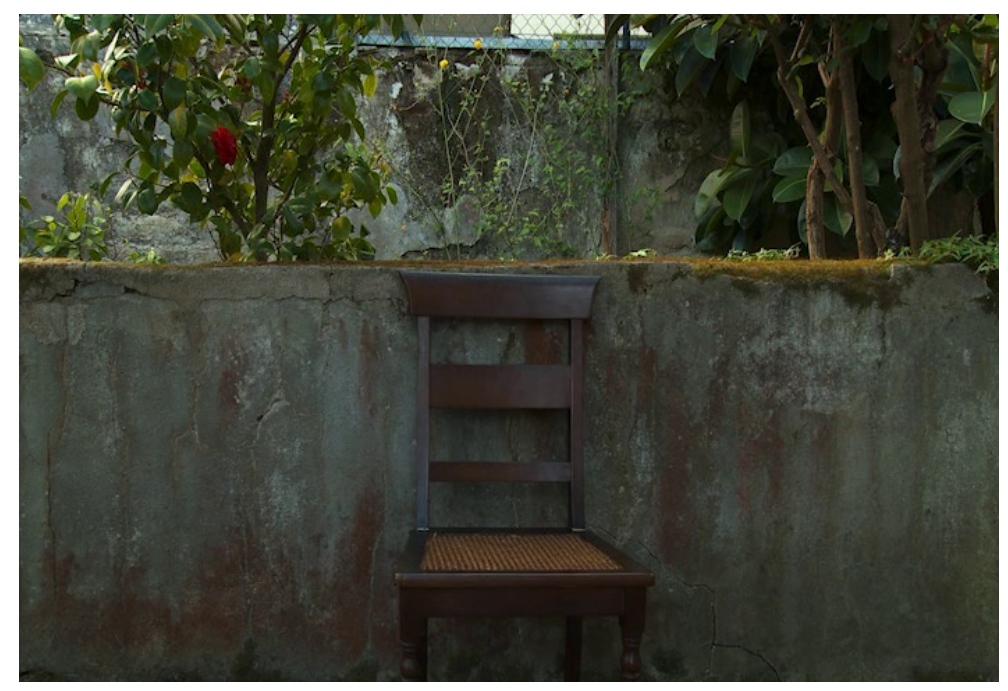

F1. A cadeira vazia, fotograma reproduzido com recorrência nas análises desse documentário. Fonte: Os dias com ele (Maria Clara Escobar, 2013).

Mais que todas as características acima descritas, uma passagem do filme em particular atraiu sobremaneira as atenções: aquela em que a diretora, tendo armado o quadro para que seu pai lesse, sentado em uma cadeira junto ao muro do quintal, o mandado de prisão expedido pelos militares contra ele em 1973, tem de lidar com a recusa veemente de Carlos Henrique Escobar. A câmera fixa o aguarda. Ele entra no campo e pega a cópia do documento sobre a cadeira. Percebendo logo do que se tratava, vai de encontro à câmera, 
contra a filha atrás da câmera, devolvendo-lhe a papelada. Indignado, ele diz: "Eu não preciso disso, preciso?" A voz de Maria Clara vem dos bastidores: "Não, eu quero que você leia." O corpo dele de início vai se movendo colado à objetiva, até que sai de vez do campo. Começa então uma dura discussão invisível entre os dois, em off. Na tela, resta a cadeira vazia, em um longuíssimo plano, de mais de seis minutos $(\mathrm{F} 1)$. O espectador vai ouvindo as vozes que surgem de fora do campo: o pai se recusa a conceder a palavra a seus algozes por meio daquele documento oficial da ditadura; questiona com aspereza o projeto fílmico da filha, querendo saber quem é o verdadeiro retratado, se ele ou ela; refuta o papel de "meu papai", dizendo que a filha desconhece sua importância. Maria Clara reage como pode: diz que aquele é, sim, um filme sobre seu pai e seu país; retruca afirmando que não está em uma posição confortável naquelas filmagens. Carlos Henrique dá a discussão por encerrada, cruza o quadro e deixa a filha só detrás da câmera. A cena pensada pela diretora não se realizará. Ainda assim, em um gesto de desobediência, ela sai dos bastidores, invade o quadro, senta-se na cadeira e lê o mandado de prisão.

O revés da reconstituição. O vazio da imagem. Essa passagem específica de Os dias com ele parece concentrar as premissas centrais da ideia de irrepresentável, matriz teórica em torno da qual gravita, com distintas aproximações, boa parte da bibliografia dedicada a este filme (cf. Feldman, 2014, 2016b, 2017; Fontes, 2015; França \& Machado, 2014a, 2014b; Maia, 2014, 2015a, 2015b; Parada, 2015; Veiga, 2016a, 2016b). É verdade que, globalmente, a fortuna crítica de Os dias com ele inclui vertentes de análise que não se colocam sob o espectro do irrepresentável. Por um lado, há abordagens que vão além da retórica do vazio, reconhecendo uma potência da representação em estado latente no cerne das aporias (cf. Arthuso, 2013; Barrenha, 2013; Barrenha \& Piedras, 2014; Brasil, 2013; Holanda, 2015; Marques, 2015; Migliorin, 2013, 2015). Por outro, a análise desenvolvida por Reinaldo Cardenuto (2018) examina os duelos entre o pai (intelectual público à moda antiga) e a filha (documentarista contemporânea da subjetividade) mantendo sempre em vista as questões propriamente históricas em jogo. Porém, nesse universo de textos, é possível identificar uma linha de força 
interpretativa que, manifestando-se a partir de diferentes entradas conceituais - o "fracasso", a "performatividade", a "indeterminação", entre outras variantes tributárias do "giro linguístico" -, coloca a irrepresentabilidade do trauma e da história em primeiro plano. Nessa linha, é como se a cadeira vazia de Os dias com ele fosse o emblema de algo bem maior: as ausências no núcleo das rememorações elaboradas na cinematografia dos descendentes de militantes vítimas do autoritarismo no Brasil e no Cone Sul. ${ }^{2}$ Aquela cadeira em particular é elevada, no limite, a símbolo de uma lacuna constitutiva, de um abismo intransponível entre memória e passado, entre linguagem e realidade. A crise epistemológica reveste-se aí com a dramaticidade da experiência traumática. As aporias se sobrepõem, o referente histórico não cabe nas representações.

Esse é um longo debate. Remontando aos combatentes emudecidos que voltavam das trincheiras da I Guerra Mundial, passando pelas tentativas de elaboração da Shoah, o irrepresentável é um conceito-chave nos estudos da memória de experiências extremas, estendendo-se às ditaduras do Cone Sul (Benjamin, 1994, pp. 114-115; Sarlo, 2007, pp. 23-44). Algumas das polêmicas acerca dessa pauta se tornaram célebres, seus termos se difundiram e seguem vigentes em contextos analíticos variados - incluindo a fortuna crítica sobre o documentarismo intergeracional feito por filho(a)s e outros descendentes de militantes contrários às ditaduras do Cone Sul. As questões levantadas estão longe de terem sido superadas (cf. Huyssen, 2014, p. 13). O fogo cruzado sobre o irrepresentável vem de distintos lugares de saber, dos estudos literários, da filosofia, das reflexões sobre as imagens, da historiografia. Nomeadamente, no campo historiográfico, ressalta-se a discussão travada entre Carlo Ginzburg (2011c) e Hayden White (1992) em torno dos "limites da representação" (cf. Ricœur, 2007, pp. 261-274). No terreno das imagens, é central a controvérsia sobre o “inimaginável” levada adiante por Georges Didi-Huberman (2012) com Claude Lanzmann e seus seguidores - Gérard Wajcman e Élisabeth Pagnoux (cf. Feldman, 2016a). No âmbito da estética, cabe evocar as refutações da "hipérbole especulativa do

\footnotetext{
2 Para uma visão mais abrangente do documentarismo intergeracional sobre as ditaduras do Cone Sul, incluindo análises de outros títulos, cf. Seliprandy, 2018.
} 
irrepresentável” formuladas por Jacques Rancière (1997, 2012, pp. 119-149), tendo como alvo principal Jean-François Lyotard. Esses são apenas alguns exemplos, por ora aludidos de passagem, de acaloradas discussões suscitadas pela problemática do irrepresentável.3 Nessa arena, as referências se cruzam, as razões epistemológicas, estéticas e éticas estão intimamente entrelaçadas. Correndo o risco da esquematização, é possível identificar aí duas vertentes. De um lado, as formulações que, frente ao trauma incomensurável, diante do real inapreensível, acabam colocando toda a ênfase nas aporias da representação. Nessa linha, a realidade se torna indizível, inimaginável, entre outras variantes da intangibilidade do horror e do referente histórico. De outro, estão aqueles que insistem em enfrentar o desafio colocado pelo real, reivindicando o imperativo de uma aposta referencial. As representações, por mais inescapavelmente lacunares que sejam, oferecem, "apesar de tudo", um conhecimento possível do passado, incluindo o traumático. Como saldo fundamental dessa aposta, compreende-se também algo sobre o presente das rememorações.

Eis a simplificação de um debate complexo, é verdade, mas não seria o caso de reconstituir preliminarmente os meandros dessas discussões, adiando a entrada no objeto específico do artigo. ${ }^{4}$ Ficam aqui indicadas as leituras que nortearão a análise de Os dias com ele. Ou melhor, a bibliografia que invadirá o cotejamento proposto entre o que se vê nesse documentário e as premissas das reflexões até agora existentes sobre ele. Trata-se, no fundo, de promover uma discussão teórica a partir do filme, dando primazia à fatura audiovisual para enfrentar o espinhoso tema dos impasses e das possibilidades do representável. Esta análise toma partido, claro, em mais de um sentido. Lidando com seus materiais, os historiadores têm por hábito desorganizar os arcabouços conceituais. Tal impulso está às voltas, justamente, com os limites das representações, com os esquematismos das categorizações, enfim, com os traços fugidios dos vestígios. A própria noção de irrepresentável não poderia sair ilesa dessa indagação.

3 O "realismo especulativo" é outra vertente teórica que vem lidando com os impasses da incognoscibilidade das "coisas em si”, buscando superá-los (cf. Bezerra \& Gonçalo, 2018). 4 Para um panorama desses embates teóricos no campo da História, cf. MALERBA, 2006. 
No geral, há uma prolixidade do indizível nas análises de Os dias com ele filiadas à matriz do irrepresentável. E essa espécie de redundância do indizível não é incomum no contexto dos estudos do cinema documentário contemporâneo em geral. Ora, é inegável que as lacunas estão inscritas nas imagens de Os dias com ele, seja naquilo que se fala (nesse caso, nos embates e esquivas entre pai e filha), seja naquilo que se vê (na cadeira vazia, na crueza dos recursos cinematográficos, nas tensões entre campo e extracampo etc.). A questão que se coloca é outra. Não se está aqui recusando às imagens de Os dias com ele sua carga de impasses. Mas cabe perguntar se essas imagens só dão a ver aporias, e nada mais do que isso.

Se as aporias se impõem na maior parte das interpretações da passagem da cadeira vazia, vale lembrar que a dimensão problemática da representação não está toda concentrada na imagem daquela cadeira. Outros momentos do filme trazem essa pauta à tona de modo explícito. Bem antes, na primeira tentativa de Maria Clara Escobar em tocar no tema da tortura com o pai, o lapso auditivo de Carlos Henrique é eloquente: a filha pergunta sobre a questão da tortura; ele entende "cultura". A confusão com as palavras é apenas a primeira esquiva, talvez inconsciente, de Carlos Henrique ao ser convocado a rememorar a experiência dolorosa. Maria Clara repete, "tor-tura”. "Uma pergunta boa, entretanto, difícil", Carlos Henrique introduz sua resposta. Para não responder. Filósofo, ele encontra refúgio na teoria: "O Derrida tem textos sobre testemunho. Ele mostra como é impossível um testemunho se aproximar da verdade." Anuncia em seguida: "Então, eu vou falar agora do que [a tortura] significou para mim.” Mas, antes, vai desfiando uma série de considerações preliminares: sobre as especificidades da tortura ao longo da história, citando Marx; sobre as diferenças entre testemunhos de pessoas torturadas; para concluir: "Estamos falando de alguma coisa que a imagem não tem muito poder, estamos falando de alguma coisa em que as palavras se perdem através das metáforas e das singularidades”. E justifica: "Levando em conta tudo isso para que o meu depoimento não tenha nenhuma pretensão de verdade.” Tendo novamente anunciado seu relato pessoal, Carlos Henrique retorna aos preâmbulos. Fala sobre o caráter injustificável da tortura e volta a concluir: "Não é fundamental aqui entender. 
Já porque não existe verdade de nada. Mas o fundamental não é que eu diga alguma coisa próxima à verdade desta situação.” As pernas agitadas e o insistente bater das mãos nos braços da poltrona são sinais corporais do desconforto desencadeado pela pergunta difícil da filha. A resposta sobre a experiência da tortura é suspensa, fica adiada pelos preâmbulos sobre a tortura em geral. O que Carlos Henrique vem repetindo até esse ponto é, justamente, a natureza irrepresentável da tortura: "As pessoas silenciam mesmo. É difícil alguém falar sobre isso. Eu falei que é difícil fazer imagem, é difícil fazer cena dramática, é difícil até escrever, são complicados os testemunhos, eu falei para você."

As leituras da cadeira vazia em geral concentram-se justamente nessa impossibilidade, como que ecoando aquilo que o entrevistado diz nesse momento específico do filme. De fato, o caráter problemático da representação não apenas é enunciado pelo pai, mas também está inscrito em certas opções formais e narrativas do documentário da filha. Seja na reflexividade implícita pela inclusão no corte final daqueles momentos que Carlos Henrique supõe serem o antes e o depois da entrevista; seja pela crueza dos enquadramentos; seja, ainda, pela reiterada frase "Este não é o meu pai" acompanhando as filmagens de arquivo em super-8 de famílias alheias - frase que, em certo sentido, faz lembrar a célebre provocação "Isto não é um cachimbo", de René Magritte.

Por vias distintas, certas interpretações de Os dias com ele compartilham com o Carlos Henrique filósofo a matriz do irrepresentável, muitas vezes realizando um movimento análogo ao dele na passagem recém-descrita: colocar entre as imagens e sua discussão o anteparo da teoria. Não deixa de haver certa homologia entre as tergiversações abstratas de Carlos Henrique na primeira tentativa da filha de extrair dele um relato sobre a tortura e as análises do filme na chave do irrepresentável que mobilizam um robusto arsenal teórico (cf. França \& Machado, 2014a, 2014b; Feldman, 2014; Maia, 2014, 2015a, 2015b; Veiga, 2016a, 2016b). Em certos casos, o aparato conceitual acaba ocupando em tal medida as análises a ponto de quase invisibilizar as imagens fílmicas. Isso não deixa de ser um sintoma de certa 
"inflação teórica" (Sarlo, 2007, p. 95) observável nesse campo de estudos. O saldo final é um déficit de historicidade, um exaurimento do horizonte referencial. Sobra o irrepresentável.

De forma alguma a leitura proposta neste artigo busca uma interpretação da matéria audiovisual "expurgada" da teoria, como se fosse possível olhar para as imagens em sua pura concretude referencial. As "contra-análises" de Marc Ferro (2010), pioneiro dos cruzamentos entre cinema e história nos anos 1970, já estavam bem distantes da verificação imediata da fidedignidade de um filme. A análise historiográfica das imagens dos filmes se faz aqui com a teoria. Na verdade, com alguns dos mesmos teóricos correntemente citados em nome de um esvaziamento do referente. A presença constante de Jacques Rancière e Georges Didi-Huberman na fundamentação dessas leituras do irrepresentável é algo que causa estranheza. Afinal, Rancière (1997, 2012) possui escritos que desenvolvem uma incisiva desconstrução dialética da "hipérbole" do irrepresentável. Didi-Huberman (2012), aquele que insiste em reivindicar o imaginável malgré tout, muitas vezes parece ser apropriado malgré lui. É intrigante que o discurso do indizível, do fracasso e do vazio possa tomar como referência aquilo que escrevem esses dois autores.

A inquietação quanto à ideia de irrepresentável atravessa a discussão promovida por Rancière sobre as distinções entre o regime representativo e o regime estético das artes. Nesse contexto, ele escreve:

[...] sob que condições é possível declarar certos acontecimentos irrepresentáveis? Sob que condições pode-se dar a esse irrepresentável uma figura conceitual específica? Sem dúvida essa indagação não é neutra. É motivada por certa intolerância quanto ao uso inflacionista da noção de irrepresentável e da constelação de noções vizinhas: o não apresentável, o impensável, o intratável, o indesculpável. Esse uso inflacionista, de fato, engloba sob o mesmo conceito e envolve com uma aura de terror sagrado os mais diversos fenômenos, processos e noções [...]. A questão é saber como e em que condições é possível construir tal conceito que se propõe a abarcar univocamente todas as esferas da experiência. (Rancière, 2012, p. 119).

Essa inflação do irrepresentável tem um efeito claro para Rancière (2012, p. 122): "transformar os problemas de regulagem da distância representativa 
em problemas de impossibilidade de representação.” O autor prossegue: “[...] não há nenhuma propriedade do acontecimento que vete a representação, que interdite a arte no sentido próprio do artifício. Não há o irrepresentável como propriedade do acontecimento. Existem somente escolhas." (Rancière, 2012, p. 139). E, ainda: "A alegação do irrepresentável afirma que há coisas que só podem ser representadas num certo tipo de forma, por um tipo de linguagem própria à sua excepcionalidade. Stricto sensu, esta ideia é vazia." (Rancière, 2012, p. 147).

Georges Didi-Huberman (2012) desdobra a polêmica sobre o irrepresentável ao enfrentar sua manifestação específica no campo das imagens: o inimaginável. Em Imagens apesar de tudo, o autor discute as quatro fotografias que documentam o horror em ato em Auschwitz, tiradas por membros do Sonderkommando ("comando especial" composto por judeus prisioneiros forçados a realizar as tarefas básicas do extermínio de seus semelhantes) com apoio da resistência polonesa. Igualmente incisivo em seu posicionamento "contra todo e qualquer inimaginável", ele escreve:

Basta ter olhado uma vez para este resto de imagens, para este corpus errático de imagens apesar de tudo, para sentir que já não é possível falar em Auschwitz nos termos absolutos - geralmente bem-intencionados, aparentemente filosóficos, na realidade preguiçosos - do "indizível” e do “inimaginável”. [...] Disse-se que Auschwitz era impensável. Mas [...] o ponto em que o pensamento fracassa é justamente aquele em que devemos persistir nele, ou, mais precisamente, imprimir-lhe uma nova direção. [...]

Nesta tarefa, o papel do historiador é seguramente capital. Ele não pode, nem deve "permitir que nos desembaracemos do problema representado pelo genocídio dos judeus relegando-o para o impensável [...]”. (Didi-Huberman, 2012, pp. 41-42, grifo do autor).

Como é possível incluir as obras de Jacques Rancière e Georges DidiHuberman, mesmo que outros livros, entre as referências que sustentem as leituras do irrepresentável? Como evocar as ideias desses teóricos para tecer considerações que não vão muito além do vazio da cadeira de Os dias com ele? É certo que toda releitura, que toda passagem de uma teoria de um contexto analítico para outro trará sempre consigo uma transferência 
conceitual (Espagne, 2013). Mas há uma diferença substantiva entre a inevitável transferência de uma formulação e sua completa inversão. A impressão é que, de modo geral, faz-se um uso desmesuradamente livre dos textos desses teóricos, pinçando-se frases isoladas aqui e ali para estimular certas ideias, e não exatamente uma interpretação que leve em conta as estratégias que constituem globalmente a argumentação em pauta. 5 No caso de Rancière e Didi-Huberman, esse tipo de "uso livre" ajudaria a explicar tal apropriação para defender exatamente aquilo que esses autores refutam em suas obras. Porém, uma leitura cerrada dos textos aqui mobilizados revela que ambos são duros nas críticas que fazem ao viés do irrepresentável. No fundo, a inflação teórica nas leituras do irrepresentável tem muito de desatenção conceitual.

Ao contrário do que se diz, nas leituras do irrepresentável, o fracasso nem chega a ser um risco porque ele já é um dado de saída. Por inflação, por hipérbole, as distâncias, inadequações, desproporções, desorientações, dificuldades e defasagens no cerne de toda representação são transformadas em um impossível absoluto. Quanto a isso, vale esclarecer: é óbvio que esta crítica não se volta contra o indivíduo que vive uma experiência a qual considera irrepresentável. O próprio Carlos Henrique Escobar manifesta esse sentimento, essa aporia, enquanto tergiversa diante da pergunta da filha sobre a tortura sofrida. O problema se dá quando esse irrepresentável da esfera da experiência individual é elevado à condição de dogma teórico por aqueles que se dedicam a interpretar as representações: filmes, livros, peças, instalações, fotografias etc. os quais, apesar de todos os impasses, foram realizados e estão disponíveis para a análise (Didi-Huberman, 2012, pp. 8687). A questão discutida nestas páginas é de ordem epistemológica, não custa lembrar. Ela diz respeito, de saída, ao limite interno de uma premissa teórica que, paradoxalmente, interdita a compreensão. Pois há um círculo tautológico no qual ficam presas as abordagens do irrepresentável. Quando a

\footnotetext{
5 Sobre isso, Umberto Eco $(2004$, p. 44) já escreveu: "E um texto outra coisa não é senão a estratégia que constitui o universo de suas interpretações legitimáveis - se não 'legítimas'. Qualquer outra decisão de usar livremente um texto corresponde à decisão de ampliar o universo do discurso. A dinâmica da semiose ilimitada não o veda, e até chega a encorajá-lo. Mas cumpre saber se queremos exercitar a semiose ou interpretar um texto.”
} 
impossibilidade está instalada definitivamente no ponto de partida de todo esforço de representação, o ponto de chegada não pode ser outro senão o fracasso. E, assim, as análises partem da premissa da impossibilidade da representação para concluir, no fim do percurso analítico, pela impossibilidade da representação. Não se assume nenhum risco nesse tipo de leitura, não há qualquer tensão em jogo: apenas um fracasso assegurado $a$ priori, uma pronta desistência frente ao desafio referencial, uma preguiça intelectual que se contenta com o vazio (Didi-Huberman, 2012, p. 41, p. 60).

\section{O vazio e o vestígio}

Enxergar apenas a lacuna no filme é pouco. Mas igualmente redutor seria depurar as imagens de suas aporias, focando apenas o teor testemunhal que, sim, é palpável na fricção entre pai e filha. Um último movimento deste artigo propõe uma análise que confronta inventivamente as verdades legíveis tanto no testemunho quanto nas evasivas e nos vazios de Os dias com ele. Para isso, vale rever a passagem da cadeira vazia, fazendo um esforço interpretativo que vire do avesso a retórica do irrepresentável. Carlo Ginzburg e Georges Didi-Huberman servirão aqui de base teóricometodológica. O primeiro, de modo mais geral, ao professar um labor historiográfico em que coexistam "hipóteses arriscadas" e "rigor na pesquisa das provas" (Ginzburg, 2010, p. 250). O segundo, especificamente pelo cruzamento de duas de suas formulações. Começando pelo "duplo regime da imagem", ou seja, a ideia de que as imagens comportam em si, dialeticamente, a lacuna e o vestígio, o que foi destruído e o que sobrevive, a ausência e o resquício, uma obscuridade e uma verdade, o impossível e o apesar de tudo (Didi-Huberman, 2012, pp. 51-52, 136 e 209).

Em Os dias com ele, como já se viu, no clímax dos embates entre pai e filha, a cadeira fica vazia por um longo tempo, os dois discutem em off, fora do alcance da câmera. Contudo, no final do plano - uma tomada cuja duração fica demarcada pela redução paulatina da luminosidade natural -, quando o desacordo chega ao ápice da saída de Carlos Henrique até mesmo do fora de campo, quando ele encerra a filmagem unilateralmente - "Amanhã", ele diz 
ao abandonar a cineasta com sua câmera ligada -, enfim, quando o refluxo e o fracasso se impunham, Maria Clara irrompe na imagem, atingindo aquela superfície vazia tal qual uma turbulência (Didi-Huberman, 2012, p. 111). Os impasses que ecoavam desde o espaço invisível da cena se revertem em um gesto afirmativo de autoexposição. Ela se senta na cadeira até então desocupada e lê o mandado de prisão no centro da discórdia da vez. No jogo entre o off e o visível, entre a inércia e a turbulência, entre a retração e o afluxo, entre a ausência e a presença, entre o nada e a história - como diz Carlos Henrique na discussão com a filha -, enfim, nessas tensões que afloram da duração incomum do plano, essa imagem traz a carga do "duplo regime”. Nela se intensifica um curto-circuito em cadeia que atravessa todo o documentário: entre as gerações; entre as temporalidades; entre a resistência à opressão passada e a resistência frente à direção do filme; entre a insubmissão do militante e a desobediência da cineasta; entre a imagem pública que o intelectual deseja legar à audiência e o retrato privado que a filha insiste em arrancar daquele convívio. A tensão dos dias passados com ele se projeta em uma temporalidade histórica. Os embates da memória intergeracional são aqui de alta voltagem: nem só negatividade (o vazio da cadeira), nem só positividade (a leitura do documento oficial pela filha). A passagem da cadeira condensa uma dialética potente entre o vazio e o vestígio.

Como interpretar os termos dessa dialética? Como escapar de uma análise que concentre todas as atenções em apenas um desses polos, descartando o outro? Como extrair desse atrito uma indagação referencial? A segunda formulação de Didi-Huberman (2012, p. 148, grifo do autor) dá uma resposta frutífera a essas questões: por meio de uma leitura que convoque "todos os elementos do saber - documentos escritos, testemunhos contemporâneos, outras fontes visuais - suscetíveis de serem reunidos pela imaginação histórica numa espécie de montagem ou de puzzle [...]”. Vale esclarecer: “imaginação" aqui não significa invenção. Defendendo uma historiografia que conjugue criativamente provas e possibilidades, Ginzburg (2011b, p. 334) alerta: das muitas soluções disponíveis ao historiador para lidar com as lacunas do passado, "entre as que certamente têm que ser excluídas está a 
invenção”. Aqui a reivindicação da inventividade histórica - diferente da invenção - se dá em função da cognição, da busca de um conhecimento que assume a forma de uma montagem. Colateralmente, a intenção é demonstrar que a interpretação historiográfica, ao contrário da caricatura positivista muitas vezes traçada pelos adeptos do irrepresentável, não ignora a dimensão imaginativa. Via de regra, são as leituras do irrepresentável que carecem de imaginação e de originalidade, repetindo sempre os mesmos tópicos da doxa contemporânea, descartando precipitadamente "todos os elementos do saber” que escapam à retórica do vazio.

Ocupando a cadeira, Maria Clara Escobar tem em mãos uma cópia do mandado de prisão expedido contra o pai pelo Ministério do Exército. "Tudo isso é deles, é uma mentira, é a burocracia deles”, Carlos Henrique havia dito, querendo, com pleno direito, não dar voz a seus algozes. As análises que descartam de saída o teor do mandado como que acatam esse interdito, ficando só com o polo vazio da dialética. Mas vale aqui seguir a filha em sua desobediência e ler com ela o documento:

Tenho a honra de comunicar à Vossa Excelência que, nesta data, cumprindo diligências e investigações impostas pelo Inquérito Policial Militar do qual sou encarregado, expedi mandado de prisão contra Carlos Henrique de Escobar Fagundes, por prática de atividades subversivas ligadas à organização denominada Resistência Armada Nacional (RAN), nos termos da legislação vigente. Informo, outrossim, à Vossa Excelência que os citados indiciados se encontram presos em dependências do I Exército. Aproveito a oportunidade para renovar à Vossa Excelência os protestos de alta estima e respeito. Ministério do Exército, I Exército, Rio de Janeiro, 27 de abril de 1973.

É “a burocracia deles”, sem dúvida. Um texto frio, protocolar, lido por Maria Clara em tom monocórdio. Mas é só aí que o espectador acaba informado sobre a organização de esquerda à qual Carlos Henrique estava ligado: a Resistência Armada Nacional (RAN), grupo clandestino que começou a se formar no segundo semestre de 1969 e cuja linha política fundia marxismo e nacionalismo revolucionário. Com foco de atuação entre setores da classe média e dissidentes nacionalistas no interior das Forças Armadas, de início sua base era composta sobretudo por quadros oriundos da tentativa de 
guerrilha na serra do Caparaó, incluindo militantes remanescentes do Movimento Nacionalista Revolucionário (MNR). Em dezembro de 1970, a publicação do jornal intitulado Independência ou morte foi um dos primeiros passos da nova agrupação que surgia, a qual só posteriormente, em 7 de setembro de 1972, adotaria a denominação RAN. No início desse mesmo ano, a RAN funda outra revista, a Prisma, acrônimo para "Pensamento Revolucionário Intelectual Socialista Marxista”. Estruturada no Rio de Janeiro e em Minas Gerais, a RAN não teve muito tempo de levar seus projetos adiante. No início de 1973, tão logo desencadeara as primeiras, e simples, ações armadas, foi desbaratada pela repressão nos dois estados onde existia. Ao longo de abril daquele ano, quase uma centena de pessoas acusadas de integrá-la foi detida. Carlos Henrique Escobar estava entre elas. Todos esses dados sobre a RAN constam no Tomo III do projeto Brasil: nunca mais, dedicado a traçar o "Perfil dos Atingidos" pela violência ditatorial (Arquidiocese de São Paulo, 1985, pp. 101-102). ${ }^{6}$ Como se sabe, esse projeto encabeçado pela Arquidiocese de São Paulo foi um marco inicial importantíssimo para o esclarecimento das atrocidades cometidas pelo regime brasileiro. Diferentemente do congênere Nunca más argentino (Comisión Nacional sobre la Desaparición de Personas, 2011), fundado principalmente na coleta dos testemunhos orais dos sobreviventes (cf. Crenzel, 2014), o Nunca mais brasileiro teve como fonte, precisamente, a papelada oficial gerada pela burocracia da Justiça Militar (Arquidiocese de São Paulo, 1998, pp. 22-24).

A incorporação de materiais extrafílmicos é neste ponto um movimento consciente da análise, seguindo a trilha do arquivo sinalizada pelo gesto de desobediência da filha inscrito na imanência das imagens de Os dias com ele. Debruçando-se sobre essa enorme massa documental, perscrutando as 3.719 páginas do arquivo BNM 701, referente à ação penal contra a RAN do Rio de Janeiro que se estendeu entre 1973 e 1979, é possível ter uma ideia acerca da natureza da militância de Carlos Henrique de Escobar Fagundes. Àquela altura, pelo que se extrai dos documentos, ele era professor na Escola de

${ }^{6}$ Sobre a RAN, cf. também: Ridenti, 2010, p. 31; Maciel, 2009, p. 124-127. 
Comunicação da Universidade Federal do Rio de Janeiro e havia prestado serviços de tradução para importantes casas editoriais, como a Edições Tempo Brasileiro e a Zahar Editores (BNM 701, 2013, pp. 1859, 2392 e 2394). Essas pistas conduzem à informação de que Carlos Henrique era um colaborador assíduo da revista Tempo brasileiro, ligada à primeira editora. $\mathrm{E}$ também de que, pela Zahar, ele traduziu, por exemplo, uma compilação de ensaios intitulada Marxismo e estruturalismo, bem como o livro A formação do pensamento econômico de Karl Marx, de Ernest Mandel, ambos publicados em 1968. Quanto à militância mais direta, pelo exame do arquivo BNM 701 fica-se sabendo que Carlos Henrique Escobar integrava um dos três Grupos de Ação (GA) da revista Prisma, ligada à RAN. Os documentos da ação penal vão deixando rastros esparsos acerca dessa publicação clandestina. Sobre seu teor, há indicações a respeito de pelo menos duas das edições da Prisma. Uma delas teria sido dedicada, ao que consta por sugestão de Carlos Henrique, ao tema "O poder", discutido em duas partes: a primeira baseada na obra de Lênin referida como $O$ que é o Estado; a segunda a partir de um artigo de João Quartim de Moraes, "A natureza de classe do Estado brasileiro", publicado na revista Les Temps Modernes em 1971 (BNM 701, 2013, p. 3227). Outro número da Prisma teria tido como tema a figura de Tiradentes (BNM 701, 2013, p. 169-170). Os integrantes dos GAs da revista contribuíam mensalmente para o sustento financeiro da publicação, a qual ainda era vendida por cinco cruzeiros para os militantes. A princípio, a intenção era que a revista tivesse periodicidade mensal, mas as dificuldades na elaboração e na distribuição fizeram com que seus números surgissem a cada dois meses (BNM 701, 2013, p. 170). Todos esses são traços do engajamento de Carlos Henrique Escobar como intelectual. Ou melhor, segundo as palavras de sua defesa registradas na ação penal: na "formação de um grupo de intelectuais que estivessem interessados em discutir sobre a realidade brasileira". Essas "tarefas não seriam realizadas abertamente, mas não seria também exigido dos participantes uma atuação na clandestinidade" (BNM 701, 2013, p. 2459). Dessa ida ao arquivo BNM 701, acaba surgindo uma imagem, sem dúvida lacunar, inevitavelmente distorcida pela sanha acusatória da repressão, mas, ainda assim, uma imagem do militante Carlos 
Henrique Escobar, de sua condição de intelectual que atuava em oposição à ditadura.7 A desobediência da filha ao ocupar a cadeira e ler em cena o documento oficial veementemente refutado pelo pai abre para esta análise o caminho dos arquivos. Emerge daí um esboço de retrato do homem público que o filósofo e dramaturgo tenta insistentemente transmitir por meio do documentário da filha.

É “a mentira deles”, ele havia retrucado. Em grande medida, sim. Mas foi pela leitura a contrapelo daquela mentira judicial que os investigadores do projeto Brasil: nunca mais conseguiram rastrear as violações documentadas pela própria máquina repressiva. Aquelas fontes, certamente, são "vidros deformantes" - "nem janelas escancaradas, como creem os positivistas, nem muros que obstruem o olhar, como creem os céticos" (Ginzburg, 2014, p. 4849, tradução nossa). Porém, isso não faz com que não haja nenhuma prova ali. Na introdução do livro que sintetiza o relatório do projeto Brasil: nunca mais, esse caráter do testemunho involuntário extraído das entranhas burocráticas da ditadura é um aspecto a ser celebrado: “o que se produzisse como constatação de irregularidades, de atos ilegais, de medidas injustas, de denúncias sobre torturas e mortes, teria a dimensão da prova indiscutível. Definitiva.” (Arquidiocese de São Paulo, 1998, p. 24). Ora, quando a fonte consultada pelo historiador provém de processos judiciais, quando aquilo que o acusado fala lhe é extraído pela tortura, o "vidro" se torna ainda mais deformante. Afinal, a tortura é uma "insidiosa técnica de interrogatório", a qual "tende a arrancar do acusado aquilo que o inquisidor crê firmemente ser a verdade" (Ginzburg, 2007, p. 30). Já o próprio projeto Brasil: nunca mais havia descrito esse vício da confissão obtida sob tortura. No início da fase policial, o acusado, tão logo sequestrado e submetido nos DOI-CODIs aos "interrogatórios preliminares" - leia-se: tortura -, "indefeso e incomunicável, era obrigado a confessar aquilo que seus interrogadores queriam, depois de longas sessões de tortura.” (Arquidiocese de São Paulo, 1998, p. 175). O mesmo relatório ressalva ainda: “As confissões obtidas nos órgãos de segurança não eram, evidentemente, livres, nem espontâneas. 
Muitas vezes, não eram sequer verossímeis, posto que as declarações tinham que concordar com as informações anteriores que as autoridades tinham sobre o detido.” (Arquidiocese de São Paulo, 1998, p. 182). Datas forjadas de prisões, falseamento de prazos legais e condições do interrogatório eram a regra, testemunhas aleatórias assinavam os documentos. Mentiras em série eram registradas nos papéis no momento de "legalizar" o Inquérito Policial Militar (Arquidiocese de São Paulo, 1998, pp. 173-176). No caso de Carlos Henrique Escobar, as incongruências sobre a data de sua prisão afloram já no documento lido por Maria Clara: o mandado é de 27 de abril de 1973, mas "os citados indiciados se encontram presos em dependências do I Exército”. Nas alegações finais em favor de Carlos Henrique e Maria da Glória Ribeiro da Silva (psicóloga e militante, companheira de Carlos Henrique à época), o advogado que os defendia desqualifica a prova que embasa a acusação de ambos, "meramente inquisitorial de natureza oral" (BNM 701, 2013, p. 2462). Essas fontes oficiais, como bem se sabe, têm inúmeras armadilhas.

Mas elas também contêm os desmentidos feitos pelos próprios acusados. Este era um aspecto curioso da burocracia repressiva brasileira: superada a fase policial do inquérito, o réu tinha a oportunidade de refutar perante a Justiça Militar aquilo que se alegava que ele houvesse confessado durante os “interrogatórios preliminares". "É que, em Juízo, na presença de seu defensor, o réu político tinha condições de negar - ou retratar - as confissões extrajudiciais e relatar o modo como elas haviam sido obtidas." (Arquidiocese de São Paulo, 1998, p. 182). No depoimento prestado à $2^{\mathrm{a}}$ Auditoria do Exército, Carlos Henrique faz exatamente isso:

[...] que o depoente foi preso no dia 15 de abril do corrente ano [1973] e levado para a PE; lá desnudaram sua esposa em sua frente e deram-lhe um soco na cara; aplicaram choques elétricos no depoente; colocaram o depoente na 'geladeira', onze dias sem comer e sem beber, onde ficava uma sirene ligada permanentemente, razão pela qual o depoente agora será submetido a uma operação no ouvido como consequência dos ruídos respectivos; [...] se não assinasse o depoimento teria a prisão preventiva, e após assiná-lo, dias depois, foi libertado. (BNM 701, 2013, pp. 1108-1109). 
Eis "a burocracia deles", mas esse trecho em especial registra a verdade de Carlos Henrique. Ainda no calor dos eventos, ele dava o testemunho que anos depois relutaria tanto em conceder à filha cineasta. Foi a partir das incontáveis passagens análogas a essa registradas na papelada oficial que o projeto Brasil: nunca mais logrou detalhar os "modos e instrumentos de tortura" empregados pelo regime brasileiro. Carlos Henrique passou pela "geladeira", e o livro Brasil: nunca mais traz uma compilação de descrições semelhantes desse método. Na mesma página, o relatório inclui descrições de outro instrumento de tortura: a "cadeira do dragão".

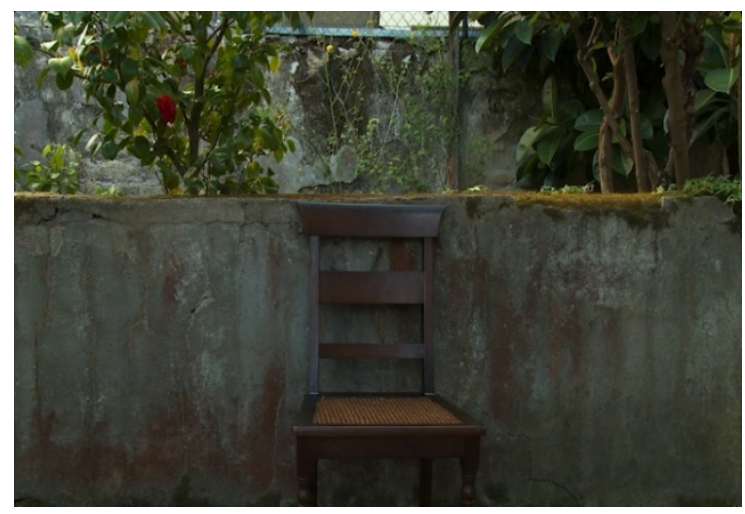

Figura 2 - A cadeira vazia e a “cadeira do dragão”. Fonte: Os dias com ele (Maria Clara Escobar, 2013).

[...] o interrogado foi obrigado a se sentar em uma cadeira, tipo barbeiro, à qual foi amarrado com correias revestidas de espumas, além de outras placas de espuma que cobriam seu corpo; que amarraram seus dedos com fios elétricos, dedos dos pés e das mãos, iniciando-se, também, então uma série de choques elétricos; que, ao mesmo tempo, outro torturador com um bastão elétrico dava choques entre as pernas e pênis do interrogado. (Arquidiocese de São Paulo, 1998, p. 37).

Imaginar a dor concreta por trás da cadeira deixada vazia por Carlos Henrique Escobar (fig. 2). A montagem propõe esse efeito de sentido, justapondo o vazio da imagem e o documento histórico. Carlos Henrique passou pela "geladeira", isso ficou registrado nos papéis oficiais e foi depois relatado no testemunho dado para a câmera da filha, quando, em uma segunda tentativa, ela insiste para que ele fale sobre a tortura. Outros passaram pela "cadeira do dragão", ${ }^{8}$ pelo "pau-de-arara", pela "pimentinha",

8 Essa mesma descrição aqui citada da versão carioca da "cadeira do dragão", compilada no 
pelo “telefone”, pelo choque elétrico, pelo afogamento, pela palmatória etc. (Arquidiocese de São Paulo, 1998, p. 34-42; Comissão Nacional da Verdade, 2014, p. 366-375). Para quem não passou por nada disso, qualquer esforço de imaginação em torno desse rol de sevícias será sempre insuficiente perante a violência física real infligida. Ainda assim, essa dor não pode ficar relegada à obscuridade dos porões, ao abismo do irrepresentável. Imaginá-la é um imperativo. As palavras documentadas atestam o horror, trazendo à luz a experiência traumática. Quando tais palavras são confrontadas com o fotograma da cadeira vazia de Os dias com ele, elas revestem aquela imagem de uma carga referencial ineludível. O registro burocrático torna-se, assim, mais do que uma prova das atrocidades cometidas pelo Estado durante aqueles anos. Ele abre uma nova gama de significados pelo choque dialético com essa imagem na qual tantas análises só viram vazio.

\section{Dialética entre aporias e apostas: um antídoto contra os abusos negacionistas}

É da dialética entre as aporias da representação e as apostas referenciais que surge um conhecimento possível sobre o passado e o presente da rememoração. Toda vez que o gesto analítico se aferra a apenas um desses polos, a abordagem reduz os termos da questão, livrando-se facilmente dos problemas. Por um lado, as leituras absolutamente concentradas no vazio ignoram o desafio colocado pela concretude histórica, contentando-se com a tautologia do fracasso. Por outro, qualquer tentativa de depurar as imagens de seus impasses em nome de uma realidade transparente cairia em uma postura epistemológica regressiva, como se fosse possível voltar à "era da inocência” positivista. Muito mais frutífero é se debruçar sobre as imagens levando em conta sua "plasticidade dialética", ou seja, a potência que têm de “produzir um efeito com a sua negação” (Didi-Huberman, 2012, p. 107, grifo do autor). Sem dúvida, as imagens de Os dias com ele dão a ver os vazios e as performances. Mas há também nelas o documento, o testemunho. A tensão

livro Brasil: nunca mais, seria depois reproduzida no tópico dedicado a esse método de tortura incluído no relatório final da Comissão Nacional da Verdade (2014, p. 367-368). 
constante entre esses opostos é o que gera a riqueza da obra fílmica e da memória intergeracional que aí se manifesta. A intepretação pela montagem convoca as referências externas sinalizadas pelas imagens, desdobrando os sentidos da rememoração em uma busca que não fica paralisada frente ao absoluto do irrepresentável, que se esforça para atestar um passado traumático. Mas não é o caso de se iludir: "Para quem quer saber e, nomeadamente, para quem quer saber como, o saber não oferece nem milagre, nem descanso. É um saber sem fim: a interminável aproximação do acontecimento e não a sua apreensão numa certeza revelada.” (DidiHuberman, 2012, p. 112, grifo do autor). A palavra "aposta" mantém as incertezas no horizonte, lembrando sempre que a aporia está no cerne de qualquer representação. Toda aposta contém um risco, a questão referencial nunca se resolve de uma vez por todas. E é exatamente por isso que entrar na arena real da memória do autoritarismo é um imperativo.

Pois o negacionismo é uma ameaça concreta que paira sobre a discussão teórica desenvolvida neste artigo (Didi-Huberman, 2012, p. 133-134). A problematização das leituras do irrepresentável feita nestas páginas diz respeito a um posicionamento epistemológico. Há aí uma defesa das potencialidades cognitivas da representação, uma aposta nas interpretações criativas em torno do referente histórico. Mas essa crítica também atende a um imperativo ético contra toda e qualquer possibilidade de negacionismo. Jacques Rancière (1997, p. 47, tradução nossa), tendo como alvo a lógica do irrepresentável, adverte: "Nosso presente é presa não do ceticismo, como se diz às vezes em tom de vantagem, mas da negação.” Carlo Ginzburg (2014, p. 42, tradução nossa) já escreveu: "O limite do relativismo é ao mesmo tempo cognoscitivo, político e moral.” Paul Ricœur (2007, p. 271), reconstituindo a polêmica entre Ginzburg (2011c) e Hayden White (1992), concluíra: “o arrazoado [do italiano] em favor da realidade do passado histórico [...] assume assim o duplo aspecto de uma atestação incontestável e de um protesto moral [...]." O sinal de alerta vinha soando há tempos: a despeito de suas intenções teóricas originais, na prática, a radicalização do relativismo cético abria um terreno fértil para o negacionismo. Vale esclarecer: não é que o prisma epistemológico do irrepresentável seja, por si só, negacionista. Em 
geral, esse viés analítico está tentando lidar, de total boa-fé e com uma franca empatia, com a dor e o trauma dos outros. A questão fica mais clara no olhar retrospectivo para Os dias com ele a partir da conjuntura brasileira pós2018: o descarte do referente (e de tudo o que possa atestá-lo) que costuma acompanhar as abordagens do irrepresentável pode ser mobilizado abusivamente por aqueles que, com má-fé ou descarado cinismo, querem relativizar ou mesmo negar um passado de atrocidades. Esse tipo de "negacionismo vergonhoso" (Rancière, 1997, p. 65, tradução nossa) vem ganhando espaço no Brasil desde 2018. Sua forma é o revisionismo conservador que tenta redimir o período ditatorial, em um diapasão que vai das releituras eruditas atenuantes à gritaria autoritária de tribunos “patriotas” (cf. Napolitano, 2015, pp. 32-35; 2017, pp. 335-343). Frente à ofensiva negacionista, nada é mais perigoso do que um discurso vazio.

\section{Referências}

Álvarez, E. C. (2010). De vuelta a casa: variaciones del documental realizado con cine doméstico. In: Álvarez, E. C. (Ed.). La casa abierta: el cine doméstico y sus reciclajes contemporáneos (pp. 121-166). Madrid: Ocho y Medio.

Arquidiocese de São Paulo (1998). Brasil: nunca mais. 29. ed. Petrópolis: Editora Vozes.

Arquidiocese de São Paulo (1985). Brasil: nunca mais. Perfil dos atingidos. Tomo III. São Paulo. http://www.dhnet.org.br/w3/bnm/tomo_iii_perfil_dos_atingidos.pd $\underline{f}$

Arthuso, R. (2013). Demasiadamente humano. Revista Cinética, jan. http://www.revistacinetica.com.br/osdiascomele.htm

Barrenha, N. C. (2013). Silêncios históricos e pessoais: memória e subjetividade no documentário latino-americano contemporâneo. In: Paiva, C. C. da S., Araújo, J. J., \& Barreto, R. R. (Org.). Cultura audiovisual: transformações estéticas, autorais e representacionais em multimeios (pp. 327-350). Campinas: Unicamp/Instituto de Artes. https://goo.gl/8gkXKa

Barrenha, N. C., \& Piedras, P. (Org.) (2014). Silêncios históricos e pessoais: memória e subjetividade no documentário latino-americano contemporâneo. Campinas: Editora Medita. (Catálogo da mostra). https://goo.gl/wxbYPu 
Benjamin, W. (1994). Experiência e pobreza. In: Benjamin, W. Magia e técnica, arte e política: ensaios sobre literatura e história da cultura (pp. 114-119). 7. ed. São Paulo: Brasiliense. (Obras escolhidas, v. 1).

Bernardet, J.-C. (2003). A entrevista. In: Bernardet, J.-C. Cineastas $e$ imagens do povo (pp. 281-296). São Paulo: Companhia das Letras.

Bezerra, J., \& Gonçalo, P. (2018). Realismo especulativo. ECO-PÓS, v. 21, n. 2, 1-11, set. https://doi.org/10.29146/eco-pos.v21i2.20510

BNM 701 (2013). Projeto “Brasil: nunca mais digit@l”. http://bnmdigital.mpf.mp.br/sumarios/700/701.html

Brasil, A. (2013). Formas do antecampo: performatividade no documentário brasileiro contemporâneo. Revista Famecos, Porto Alegre, v. 20, n. 3, 578-602, $\quad$ set.-dez. $\quad$ http://dx.doi.org/10.15448/19803729.2013.3.14512

Cardenuto, R. (2018). Memórias em negociação: o documentário brasileiro nos trânsitos entre História e subjetividade. In: Morettin, E., \& Napolitano, M. $O$ cinema e as ditaduras militares: contextos, memórias e representações audiovisuais (pp. 167-193). São Paulo: Intermeios; Porto Alegre: Famecos.

Comisión Nacional sobre la Desaparición de Personas (2011). Nunca más: informe de la Conadep. 8. ed. Buenos Aires: Eudeba.

Comissão Nacional da Verdade (2014). Relatório. Brasília: CNV. v. 1. https://goo.gl/xy97xM

Crenzel, E. (2014). La historia política del Nunca más: la memoria de las desapariciones en la Argentina. 1. reimp. Buenos Aires: Siglo Veintiuno Editores.

Didi-Huberman, G. (2012). Imagens apesar de tudo. Lisboa: KKYM.

Eco, U. (2004). Lector in fabula: a cooperação interpretativa nos textos narrativos. 2. ed. São Paulo: Perspectiva.

Espagne, M. (2013). La notion de transfert culturel. Revue Sciences/Lettres, n. 1. http://rsl.revues.org/219

Feldman, I. (2017). Do pai ao país: o documentário autobiográfico em face do fracasso das esquerdas no Brasil. In: Holanda, K., \& Tedesco, M. C. (Org.). Feminino e plural: mulheres no cinema brasileiro (pp. 213225). Campinas: Papirus.

Feldman, I. (2014). Do privado ao político: em torno de Os dias com ele. In: Estudos de Cinema e Audiovisual Socine, 17., 2013 (pp. 336-343), Florianópolis. Anais... São Paulo: Socine. https://goo.gl/DPDVUz

Feldman, I. (2016a). Imagens apesar de tudo: problemas e polêmicas em torno da representação, de Shoah a $O$ filho de Saul. ARS, São Paulo, v. 14, n. 28, 134-153, jul.-dez. http://dx.doi.org/10.11606/issn.21780447.ars.2016.124999 
Feldman, I. (2016b). Os dias com ele é filme corajoso sobre lacunas na relação com pai. Folha de $S$. Paulo, São Paulo, 20 mar. Ilustríssima. https://goo.gl/dWwDpj

Ferro, M. (2010). Cinema e história. São Paulo: Paz e Terra.

Fontes, I. (2015). A ditadura militar brasileira documentada: Os dias com ele. Guavira Letras, Três Lagoas, n. 20, 154-163, jan.-jun. https://goo.gl/mgF7UQ

França, A., \& Machado, P. (2014a). A imagem-excesso, a imagem-fóssil, a imagem-dissenso: três propostas cinematográficas para a experiência da ditadura no Brasil. In: Gonçalves, O. (Org.). Narrativas sensoriais: ensaios sobre cinema e arte contemporânea (pp. 209-233). Rio de Janeiro: Editora Circuito.

França, A., \& Machado, P. (2014b). Imagem-performada e imagematestação: o documentário brasileiro e a reemergência dos espectros da ditadura. Galáxia, São Paulo, n. 28, 70-82, dez. https://revistas.pucsp.br/index.php/galaxia/article/view/16497/1672 3

Ginzburg, C. (2007). Feitiçaria e piedade popular: notas sobre um processo modenense de 1519. In: Ginzburg, C. Mitos, emblemas, sinais: morfologia e história (pp. 15-39). 2. ed. São Paulo: Companhia das Letras.

Ginzburg, C. (2010). Investigando Piero: o Batismo, o ciclo de Arezzo, a Flagelação de Urbino. São Paulo: Cosac Naify.

Ginzburg, C. (2011a). Micro-história: duas ou três coisas que sei a respeito. In: Ginzburg, C. O fio e os rastros: verdadeiro, falso, fictício (pp. 249279). São Paulo: Companhia das Letras.

Ginzburg, C. (2011b). Provas e possibilidades (Posfácio a Natalie Zemon Davis, O retorno de Martin Guerre). In: Ginzburg, C. O fio e os rastros: verdadeiro, falso, fictício (pp. 311-335). São Paulo: Cia. das Letras.

Ginzburg, C. (2014). Rapporti di forza: storia, retorica, prova. Milano: Feltrinelli.

Ginzburg, C. (2011c). Unus testis: o extermínio dos judeus e o princípio de realidade. In: Ginzburg, C. O fio e os rastros: verdadeiro, falso, fictício (pp. 210-230). São Paulo: Companhia das Letras.

Holanda, K. (2015). Documentaristas brasileiras e as vozes feminina e masculina. Significação, São Paulo, v. 42, n. 44, 339-358, dez. https://www.revistas.usp.br/significacao/article/view/103434

Huyssen, A. (2014). Apresentação. In: Huyssen, A. Culturas do passadopresente: modernismos, artes visuais, políticas da memoria (pp. 1117). Rio de Janeiro: Contraponto.

Maciel, W. A. (2009). Militares de esquerda: formação, participação política e engajamento na luta armada (1961-1974). 212 f. Tese (Doutorado em 
História Social) - Faculdade de Filosofia, Letras e Ciências Humanas, Universidade de São Paulo, São Paulo. https://goo.gl/jPgSmh

Maia, C. (2015a). Hipóteses para Os dias com ele. In: Maia, C., \& Escobar, M. C. Duas notas sobre Os dias com ele. Rio de Janeiro: Instituto Moreira Salles. p. 5-15. (Livreto encartado no DVD).

Maia, C. (2014). História e, também, nada: o testemunho em Os dias com ele, de Maria Clara Escobar. Cinémas d'Amérique latine, Toulouse, n. 22, 140-151. http://cinelatino.revues.org/882

Maia, C. (2015b). Pequenas histórias face à grande história. Rebeca, ano 4, ed. 7, 395-415, jan.-jun. http://dx.doi.org/10.22475/rebeca.v4n1.155

Malerba, J. (2006). Teoria e história da historiografia. In: Malerba, J. (Org.). A história escrita: teoria e história da historiografía (pp. 11-26). São Paulo: Contexto.

Marques, A. R. (2015). A construção dos personagens na performance e montagem de Os dias com ele. In: Estudos de Cinema e Audiovisual Socine, 18., 2014 (pp. 422-428), Fortaleza. Anais... São Paulo: Socine. https://goo.gl/PkoqAf

Migliorin, C. (2015). Carta 4: Os dias com ele, para Maria Clara Escobar. In: Migliorin, C. Cartas sem resposta (pp. 57-64). Belo Horizonte: Autêntica Editora.

Migliorin, C. (2013). Impressões do crítico Cezar Migliorin sobre o filme Os dias com ele. $16^{a}$ Mostra de Cinema de Tiradentes, 27 jan. https://goo.gl/nvmfKv

Napolitano, M. (2014). 1964: história do regime militar brasileiro. São Paulo: Contexto.

Napolitano, M. (2017). Coração civil: a vida cultural brasileira sob o regime militar (1964-1985). São Paulo: Intermeios.

Napolitano, M. (2015). Recordar é vencer: as dinâmicas e vicissitudes da construção da memória sobre o regime militar brasileiro. Antíteses, v. 8, $\quad$ n. $\quad 15 \quad$ esp., $9-44, \quad$ nov. http://www.uel.br/revistas/uel/index.php/antiteses/article/view/236 $\underline{17}$

Odin, R. (2010). El cine doméstico en la institución familiar. In: Álvarez, E. C. (Ed.). La casa abierta: el cine doméstico y sus reciclajes contemporáneos (pp. 39-6o). Madrid: Ocho y Medio.

Parada, M. M. (2015). Cine autobiográfico femenino: éste no es mi padre. In: Estudos de Cinema e Audiovisual Socine, 18, 2014 (pp. 630-635), Fortaleza. Anais... São Paulo: Socine. https://goo.gl/PkoqAf

Rancière, J. (1997). L’inoubliable. In: Comolli, J.-L., \& Rancière, J. Arrêt sur histoire (pp. 47-70). Paris: Centre Georges Pompidou.

Rancière, J. (2012). O destino das imagens. Rio de Janeiro: Contraponto. 
Ricœur, P. (2007). A memória, a história, o esquecimento. Campinas: Editora da Unicamp.

Ridenti, M. (2010). O fantasma da revolução brasileira. 2. ed. São Paulo: Editora Unesp.

Sarlo, B. (2007). Tempo passado: cultura da memória e guinada subjetiva. São Paulo: Companhia das Letras; Belo Horizonte: Editora UFMG.

Seliprandy, F. (2018). Documentário e memória intergeracional das ditaduras do Cone Sul. 2018. 377 p. Tese (Doutorado em História Social) - Faculdade de Filosofia, Letras e Ciências Humanas, Universidade de São Paulo, São Paulo. https://teses.usp.br/teses/disponiveis/8/8138/tde-25092018125808/pt-br.php

Veiga, R. (2016a). Autobiografia "não autorizada": por uma experiência limiar no documentário na primeira pessoa. Doc On-line, n. 19, 42-59, mar. http://www.doc.ubi.pt/19/dossier_3.pdf

Veiga, R. (2016b). Por uma política da rememoração: a potência histórica do cinema de experiência pessoal. Contracampo, Niterói, v. 35, n. 3, 187210, dez. http://www.contracampo.uff.br/index.php/revista/article/view/865

White, H. (1992). Historical emplotment and the problem of truth. In: Friedländer, S. (Ed.). Probing the limits of representation: Nazism and the "Final Solution" (pp. 37-53). Cambridge: Harvard University Press. 